\title{
Turkey: Recent Regulatory Developments
}

\author{
Yaprak Yuzak Kucukvar*
}

\section{Introduction}

Several regulatory restrictions are already in place in Turkey as a part of implementation of the EU REACH Regulation within the framework of harmonisation of European Union acquis. Turkish REACH-like reg ulation Kimyasalların Kaydı, Değerlendirilmesi, İzni ve Kısıtlanmasına Hakkında Yönetmelik (KKDIK) ${ }^{1}$ introduced the restrictions as of 23 June 2017 with several conditions gradually coming into force 6 months after the regulation was published. Annex XVII listing the restricted chemicals and the conditions of restrictions reflecting EU REACH Annex XVII list, recently diverged from the EU with the first amendment to the KKDIK Regulation. Although it has created some discussions in the regulatory community, the authorities in Turkey have strong reasons for amending Annex XVII.

\section{First Amendment to KKDIK - Annex XVII}

On the 29 November Turkish regulatory authorities made amendments to KKDIK. ${ }^{2}$ The restrictions entered into force on the same date. According to the amendment, definitions of 'Industrial and Professional Use' are now included under Article 4(bb) which defines the term 'Use' under KKDIK.

Annex XVII which lists the restrictions on manufacturing, placing on the market and the use of cer-

DOI: $10.21552 / \mathrm{icrl} / 2019 / 4 / 6$

* Dr Yaprak Yuzak Kucukvar is the Manager of REACH Global Services Group Turkey Office. For Correspondence: <yaprak@reach-gs.eu>.

1 Kimyasalların Kaydı, Değerlendirilmesi, İzni ve Kısıtlaması Hakkında Yönetmelik [2017] Turkish Official Gazette No 30105 (Mükerrer).

2 Kimyasalların Kaydı, Değerlendirilmesi, İzni ve Kısıtlaması Hakkında Yönetmelikte Değişiklik Yapılmasına Dair Yönetmelik [2019] Turkish Official Gazette No 30963

3 Maddelerin ve Karışımların Sınıflandırılması, Etiketlenmesi ve Ambalajlanması Hakkında Yönetmelik [2013] Turkish Official Gazette No 28848 (Mükerrer).

4 MoEU Project Opening (2020) <https://kimyasallar.csb.gov.tr/kimyasal-guvenlik-degerlendirmesi-projesinin-acilis-semineri/314> accessed 21 January 2020. tain dangerous substances, mixtures and articles both in the EU REACH and KKDIK with the same annex number, were identical until 29 November 2019 until the first amendment to KKDIK was made. According to the amendment, a new entry is introduced and entered into force restricting the public use of certain cyanide compounds. Cyanide compounds introduced with the $67^{\text {th }}$ entry to Annex XVII, shall not be placed on the market for sale to the public as substances and shall not be sold on the Internet or on any other online platform in Turkey as of 29 November 2019. Moreover, certain conditions are set for the compliance of cyanide compounds for industrial and professional use (See Table 1).

This amendment brings along some conditions regarding labelling of these compounds in addition to the obligations set out in Turkish CLP, SEA. ${ }^{3}$ The statement 'For professional and industrial use only' must be used on the labelling of these compounds before they are placed on the market and it must be visible, legible and indelible.

Distributors and downstream users of these cyanide compounds listed under Entry 67, also have the obligation to submit 'End User Declarations' to the manufacturer or the importer, after which these declarations must be submitted to the Ministry of Environment and Urbanisation (MoEU) The provisions of KKDIK regulation and the amendments to the regulation are executed by the MoEU.

The increase in the number of suicides and crime in Turkey as a result of cyanide poisoning urged the MoEU to take measures for restricting the marketing and use of these compounds. This clearly indicates that KKDIK substance lists can diverge from EU REACH aiming for the protection of human health and the environment from the risks that can be posed by chemicals under local conditions.

\section{Instrument for Pre-Accession Assistance (IPA)Project ${ }^{4}$}

A recent IPA project co-financed by the European Union and Republic of Turkey started on 1 Novem- 
Table 1: Article 2 of Amendment to KKDIK Annex XVII Restriction Entry Details

67. Cyanide Compounds

(a) Hydrogen cyanide, Hydrocyanic acid

EC No: $200-821-6$

CAS No: $74-90-8$

(b) Hydrogen cyanide salts other than those listed in this en try

(c) Calcium cyanide

EC No: 209-740-0

CAS No: $592-01-8$

(d) Cadmium cyanide

EC No: 208-829-1

CAS No: $542-83-6$

(e) Dimercury dicyanide oxide; Mercury (II) oxycyanide EC No: 215-629-8

CAS No: $1335-31-5$

(f) Sodium cyanide

EC No: 205-599-4

CAS No: $143-33-9$

(g) Copper cyanide

EC No: 208-883-6

CAS No: $544-92-3$

(h) Potassium cyanide

EC No: 205-792-3

CAS No: $151-50-8$

(i) Zinc cyanide

EC No: 209-162-9

CAS No: $557-21-1$
- These compounds shall not be placed on the market for sale to the public as substances and shall not be sold on the Internet or on any other online platform

- Without prejudice to the application of the Regulation on Classification, Labeling and Packaging of the Substances and Mixtures published in the Official Gazette dated 11/12/2013 and numbered 28848, suppliers shall ensure before placing these compounds on the market that the packaging of such compounds is visibly, legibly and indelibly marked as follows: 'For professional and industrial use only'.

- The provisions of 2 shall apply one months after this entry comes into force.

- Downstream users or distributors of these compounds are obliged to provide 'End User Declaration' given in the AnnexXI of Annex 17 of the Regulation on the Registration, Evaluation, Authorization and Restriction of Chemicals published in the Official Gazette dated 23/6/2017 and numbered 30105 to the manufacturer or importer of the compounds. The manufacturer or importer of cyanide compounds submits declaration to the Ministry until the end of the month March, June, September and December each year. ber 2019. IPA is a European programme for EU candidate countries like Turkey and potential candidate countries in the Western Balkans. ${ }^{5}$ The 1,5 million EURO worth IPA project will be completed on $31 \mathrm{Oc}-$ tober 2021 which is 10 months after the KKDIK registration period starts. The beneficiary of the project; 'Technical Assistance to Conduct Chemical Safety Assessments under the scope of REACH Regulation' is the MoEU and the Chemicals Management Department who are responsible for the implementation of the KKDIK Regulation.

The main objective of the project is to strengthen the existing capacity of the governmental and industrial institutions in the area of chemical safety assessments. Chemicals management under the scope of the REACH regulation aims to improve by integrating the chemical safety assessment tool Chesar, which is available in the Turkish language in the existing online chemicals registration system; KKS. The current KKS system does not reflect the current IUCLID 6 content used in the EU for REACH Registrations. Upgrading the existing registration system, KKS in accordance with the latest IUCLID version is an important part of the project. The opening seminar of the project took place in Ankara on 8 January 2020 which created awareness within the industry, associations, institutions and universities in Turkey.

Several ECHA REACH Guidance Documents ${ }^{6}$ were translated and published by the MoEU as soon as the KKDIK Regulation was implemented in 2017. However, there are ECHA updates which also need to be reflected in the MoEU guidance documents. New guidance documents also need to be translated. All missing and outdated documents will also be reviewed and completed by the MoEU in light of the project to bring chemicals management in Turkey in line with EU's REACH Regulation. The other objective is to create and raise awareness amongst major groups and decision makers via seminars for regional authorities and industry.

5 EU Commission Regional Policy, Funding <https://ec.europa.eu/regional_policy/en/funding/ipa> accessed 21 January 2020.

6 MoEU Guidance Documents <https://kimyasallar.csb.gov.tr/rehber-dokumanlar/18 accessed 21 January 2020. 
The Chemical Safety Assessment (CSA) 'train-thetrainer' course is also a part of this project including study visits to ECHA and an EU Member State. The course is open to 30 participants and it is highly important how these participants will be chosen as it will directly influence the effectiveness of the project. Just like in EU REACH, CSA must be performed for all substances subject to registration, equal to 10 tonnes or above per year and Chemicals Safety Report(CSR) should be prepared according to Article 15 of KKDIK. CSR which is KGR acording to KKDIK abbreviations must be prepared by a certified risk assessor (KDU). The conditions for becoming a KDU are clearly defined in Annex XIIX of KKDIK. The candidates are requested to complete a minimum of 64 hours of training and succeed in the competency exam to qualify for the Chemical Safety Assessor Certificate. Therefore, it is anticipated that the trainers benefiting from the IPA project will eventually train the KDUs who will use Chesar tool in practice.

\section{Update on Turkish CLP, SEA}

The Turkish By-Law on the Classification, Labelling and Packaging of Substances and Mixtures ${ }^{7}$ (SEA) entered into force on 11 December 2013 and is an implementation of EU CLP Regulation. It must be noted that KKDIK and SEA cannot be separated when it comes to compliance. Both regulations are managed through the same online IT system, KKS. To be able to submit SEA notifications, companies must join pre-SIEF. Hence, substances with no obligation

7 See (n 3). to register may be present in the pre-SIEF as a result of KKS functioning. It is the responsibility of the company to oversee both regulations and determine obligations through KKS.

A draft Amended SEA Regulation that already went through a series of consultations in Turkey reflecting ATP 13 of EU CLP is currently ready for signature at the Ministry. It has been stated by the Ministry officials that the updated SEA regulation in line with EU CLP will be published this year. The MoEU is also planning to publish the Annex 6 of CLP Regulation on the web site as EU Regulations are frequently updated. Poison Centre Notifications, which will be managed by the Ministry of Health in Turkey, is also included in the updated SEA regulation.

\section{Conclusion}

The ongoing IPA Project, continuous updates to the KKDIK, SEA Regulations and online KKS system are efforts to harmonise Turkish chemicals regulations with the EU. Although there is still a long road ahead until all chemicals are registered, initial Substance Information Forum (MBDF) communications have already started for some of the substances. Multinational companies are ahead of the game as they have REACH experience and data ownership which gives them a mission to act fast with hundreds of substances to register for KKDIK compliance.

The pre-registration phase continues until the end of 2020, however the latest figures show that 63.000 pre-MBDF and 41.000 CL Notifications were submitted to the MoEU via KKS and pre-registrants can start discussing the registration and data requirements. The 'no data, no market principle' applies to companies who need to comply with KKDIK. 